\title{
Development of unique buttermilk by incorporation of Moringa
}

\author{
Binjan K. Patel", Sunil M. Patel and Suneeta V. Pinto \\ Department of Dairy Engineering, SMC College of Dairy Science, Anand Agricultural University, Anand-388110 \\ (Gujarat), INDIA \\ *Corresponding author. E-mail: binjanpatel7@gmail.com
}

Received: June 24, 2016; Revised received: December 28, 2016; Accepted: February 15, 2017

\begin{abstract}
The present investigation was aimed at formulating a fermented beverage with incorporation of Moringa Pod Powder (MPP) to develop therapeutic buttermilk. Dahi (prepared from standardized milk) mesophilic/ thermophilic dahi culture. Optimisation of the product formulation was done by using Response Surface Methodology (RSM) with central composite rotatable design (CCRD) with varying levels of MPP, total milk solids (TMS) in buttermilk and acidity of dahi. It was found that $5.60 \%$ TMS, $0.90 \%$ acidity of dahi and $1.92 \%$ MPP gave the most acceptable product with a desirability of 0.917 which is very high. From amongst various stabilizers, it was found that a blend of $0.04 \%$ pectin and $0.015 \%$ carrageenan most suitable and addition of salt, sugar and spices blend @ 0.5 $\%, 4.0 \%, 0.5 \%$ respectively were most acceptable. The proximate chemical composition of Moringa Pod Buttermilk (MPBM) was $11.77 \%$ total solids, $1.51 \%$ protein, $1.84 \%$ fat and $0.89 \%$ ash. One serving size (300 g) of MPBM could be an "excellent source of calcium" having $21 \%$ Daily Value (DV). The product could be labelled as "a good source of Vitamin A, calcium and iron" providing 10, 18 and $11 \%$ DV respectively. MPBM was found to have considerable amount of Potassium and Vitamin C and fiber (9.0, 9.0 and $6.5 \%$ DV respectively). The shelf-life of the product was 20 days under refrigeration $\left(7 \pm 2^{\circ} \mathrm{C}\right)$. The developed product is rich in fiber and iron, that is conventionally deficient in milk and hence makes the developed product complete food.
\end{abstract}

Keywords: Buttermilk, Chhash, Drumstick Moringa, Moringa pod

\section{INTRODUCTION}

Buttermilk is traditionally known as "Chhash" (Gujarat and MP), "Mattha" (UP and Delhi), "Tak" (Maharastra), "Ghol" (Bengal). Chhash is also popular, as sour buttermilk, in several other parts of the world i.e. East Asia, Africa, Europe, etc. It has uniform thick consistency, smooth texture, mild pleasing flavour resulting from a blend of clean acid taste and delicate aromatic flavour and it should be free from off flavours (Rao, 2003). The colour of the cultured buttermilk varies from yellowish creamy white for cow milk to creamy white for buffalo milk (Chandan 2006).

The milk fat and total solids in buttermilk vary between 0.5 to $1.5 \%$ and 4.5 to $5.5 \%$ respectively. Recently, the production of buttermilk on commercial scale has been taken up largely by some reputed dairy plants such as Amul, Nestle, Danone, Go and Mother Dairy. Most of the available products are flavoured with herbs, spices and condiments (Salem et al. 2013). Moringa is very impressive and amazing plant due to its tested, trusted and potential benefits from nutritional as well therapeutical points of view. The pods and leaves of drumstick are considered as one of the most nutritious foods to be found in the plant kingdom. Moringa leaves contain about 7 times the vitamin C found in orange, 4 times the calcium and 2 times the protein found in milk, and 43 times the vitamin A found in carrot and 3 times the potassium found in banana (Pandey, 2013). Drumstick pods are rich source of calcium, iron and fibre out of which $40 \%$ is soluble dietary fibre. The nutrient value per $100 \mathrm{~g}$ raw drumstick pod is Carbohydrates: $8.53 \%$, Proteins: 2.10 $\%$, Total fat: $0.20 \%$, Cholesterol: $0 \%$, Dietary fibre: $3.2 \%$. (USDA National Nutrient Database). The pods of drumsticks are used as vegetables and have great nutritional and medicinal value. Nutritionally, drumstick pods are of great value as sources of calcium, phosphorus and vitamin C. Edible portion of drumstick pods are rich in calcium $(30 \mathrm{mg} / 100 \mathrm{~g})$, phosphorus $(110 \mathrm{mg} / 100 \mathrm{~g})$, iron $(5.3 \mathrm{mg} / 100 \mathrm{~g})$ vitamin C (120 $\mathrm{mg} / 100 \mathrm{~g}$ ). Fresh pods and seeds are a good source of oleic acid. Dried Moringa seeds contain about $35 \%$ of an oil rich in oleic acid. The oil has high oxidative stability resulting in part from its fatty acid composition and from the presence of the flavones myricetin which is a powerful antioxidant (Fahey, 2005). There is a need to develop new value added dairy products to reflect consumer interest in health (e.g. utilizing vegetable source with phytochemicals) and naturalness. Moringa can be a good tool to combat not only vitamin A deficiency, but also other micronutrient deficiency at a global level. Incorporation of compact form of Moringa can be envisaged as an effective and efficient 


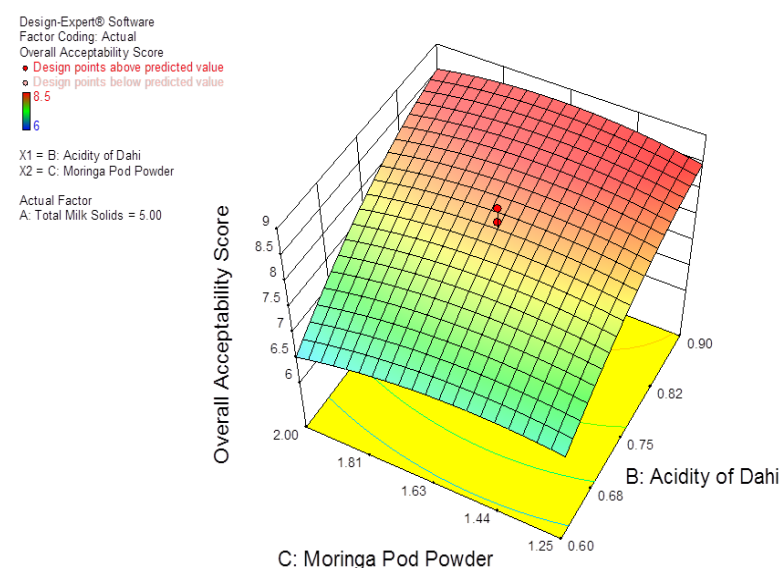

Fig. 1. Response surface of acidity (\% LA) as influenced by level of (A) Total Milk Solids (\%) and (C) Moringa Pod Powder (\%).

tool to eradicate nutritional parity of the country, which can be very well done by adding it to conventional daily use products like buttermilk and other fermented products in order to overcome its bitter taste and hence its use as a potential nutrition booster. Moreover, drumsticks are rich in dietary fibers and it has been postulated that fibers can provide a multitude of functional properties when they are incorporated in food systems (Madukwe et al., 2013). Dehydrated drumstick powder is an integral part of Indian cuisine and is extensively used in many food and curry preparations since it gives a distinct palatable taste and is rich source of glutamic acid (Ramachandran et al., 1980).

Improving human health and wellness through food nutrition and innovative products is one of the priorities identified in the world. A range of innovative applications are known to enhance nutritional quality of food including novel materials and nutrient delivery mechanisms (Salem et al. 2013). Manufacturers are finding new ways to incorporate natural and innovative ingredients into dairy products for health benefits. Moringa is one such plant product which not only has an impressive range of medicinal uses with high nutritional value but also could aid in alleviating micronutrient deficiency which is prevalent at global level. In India, drumstick pod is known as munga, saragwa or saragwe and is often referred to as Moringa in generic name (Pandey, 2013). Moringa oleifera has numerous medicinal uses, which have long been recognized in the Ayurvedic and Unani systems of medicine (Mughal et al.,1999). Therefore, it was envisaged that

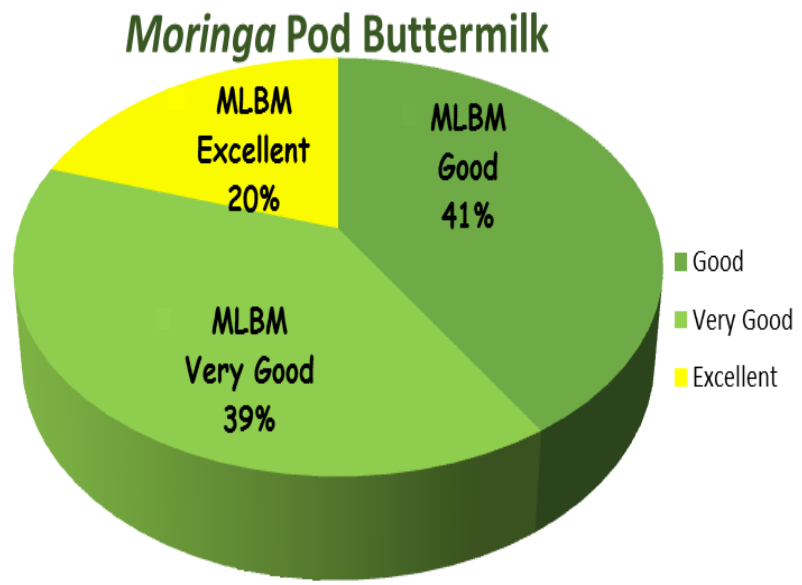

Fig. 2. Pie diagram of consumer response for Moringa Pod Buttermilk.

incorporation of drumstick in buttermilk by elevating its nutritional and functional value. Additionally, owing to the inherent virtues of drumsticks, manufacture of a drum stick based buttermilk may exert functional role improving the nutritional value of such products. The objective of present study was to develop a unique buttermilk by incorporation of drumstick that result in elevating its nutritional and functional value by increasing its iron, vitamin $\mathrm{C}$, calcium, potassium and fiber content, that is very less in conventional buttermilk, optimizing the major parameters i.e. total solids, acidity of dahi and Moringa powder and accessing the shelf life of developed product.

\section{MATERIALS AND METHODS}

Standardized milk $(4.6 \pm 0.2$ / 8.6 $\pm 0.05 \%)$ was used as the base material for preparation of buttermilk. The starter culture used for preparation of dahi was obtained from Christen Hansen Exact Dahi 2- Mat no.706272 (Freeze-dried lactic culture for Direct Vat, Denmark). This culture consists of Mesophilic/ Thermophilic culture. Moringa pod powder (MPP) was procured from Pushpam foods, Kunjrao, Gujarat. The composition of MPP was $2.2 \%$ fat, $16.1 \%$ protein, 7.6 ash, $29.5 \%$ fibre and $1.1 \%$ moisture. Cane sugar (Madhur Brand, Shri Renuka Sugars Ltd., Karnataka, non-sulphated, refined) of commercial grade and Tata brand (iodized) common salt was used. Two blend of spices consisting of mixture spices viz. Blend A consisting of cumin, dry mango powder, ginger and chilli powder and Blend B consisting of mint, black pepper and chilli powder was used for flavouring in Moringa pod buttermilk (MPBM), Low methoxy Pec-

Table 1. Experimental variables for Moringa Pod Buttermilk (coded and actual values).

\begin{tabular}{llccccc}
\hline \multirow{2}{*}{ Independent Variable } & \multirow{2}{*}{ Coded Values } & \multicolumn{4}{c}{ Coded Level } \\
\cline { 3 - 7 } & & $-2^{\mathrm{a}}$ & -1 & $0^{\mathrm{b}}$ & +1 & $+2^{\mathrm{a}}$ \\
\hline TMS (\%) in buttermilk & $\mathrm{A}$ & 5.0 & 10.0 & 15.0 & 20.0 & 25.0 \\
Acidity of dahi (\% LA) & $\mathrm{B}$ & 0.5 & 2.0 & 3.5 & 5.0 & 6.5 \\
Level of MPP (\%) & $\mathrm{C}$ & 20.0 & 25.0 & 30.0 & 35.0 & 40.0 \\
\hline
\end{tabular}

$\mathrm{a}= \pm \alpha, \mathrm{b}=$ centre point 
Table 2. Experimental design matrix and sensory scores of Moringa pod buttermilk.

\begin{tabular}{|c|c|c|c|c|c|c|c|c|c|}
\hline $\begin{array}{c}\text { Run } \\
\text { Order } \\
\text { No. }\end{array}$ & $\begin{array}{c}\text { Total Milk } \\
\text { Solids (\%) } \\
\text { (A) } \\
\end{array}$ & $\begin{array}{c}\text { Acidity of } \\
\text { Dahi (\%LA) } \\
\text { (B) }\end{array}$ & $\begin{array}{c}\text { Moringa Pod } \\
\text { Powder (\%) } \\
\text { (C) }\end{array}$ & $\begin{array}{l}\text { Flavour } \\
\text { Score }\end{array}$ & B ${ }^{\#}$ Score & $\begin{array}{l}\text { Acidity } \\
\text { Score }\end{array}$ & $\begin{array}{l}\text { C\&A* } \\
\text { Score }\end{array}$ & $\begin{array}{c}\text { OA } \\
{ }^{\circledR} \text { Score }\end{array}$ & $\begin{array}{l}\text { Acidity } \\
\text { (\% LA) }\end{array}$ \\
\hline 1 & 5.00 & 0.75 & 0.99 & 8.25 & 7.75 & 7.00 & 7.50 & 7.50 & 0.30 \\
\hline 2 & 5.00 & 0.75 & 1.63 & 8.50 & 8.25 & 7.00 & 8.25 & 8.00 & 0.25 \\
\hline 3 & 3.32 & 0.75 & 1.63 & 5.75 & 6.00 & 7.50 & 7.00 & 6.00 & 0.20 \\
\hline 4 & 5.00 & 0.75 & 1.63 & 8.50 & 8.25 & 7.00 & 8.25 & 8.00 & 0.27 \\
\hline 5 & 4.00 & 0.90 & 2.00 & 8.25 & 7.00 & 8.25 & 8.75 & 8.00 & 0.25 \\
\hline 6 & 4.00 & 0.90 & 1.25 & 8.25 & 8.00 & 8.50 & 8.50 & 8.00 & 0.26 \\
\hline 7 & 6.00 & 0.60 & 1.25 & 6.50 & 6.50 & 6.50 & 7.00 & 6.50 & 0.26 \\
\hline 8 & 6.00 & 0.90 & 1.25 & 8.50 & 8.50 & 8.50 & 9.00 & 8.50 & 0.40 \\
\hline 9 & 5.00 & 0.75 & 1.63 & 8.50 & 8.25 & 7.25 & 8.00 & 8.50 & 0.30 \\
\hline 10 & 6.00 & 0.60 & 2.00 & 6.00 & 7.00 & 5.50 & 6.50 & 6.00 & 0.25 \\
\hline 11 & 5.00 & 0.75 & 2.26 & 7.75 & 7.25 & 7.50 & 7.50 & 7.50 & 0.30 \\
\hline 12 & 5.00 & 0.75 & 1.63 & 8.25 & 8.00 & 7.00 & 8.25 & 8.00 & 0.27 \\
\hline 13 & 4.00 & 0.60 & 1.25 & 6.50 & 6.50 & 6.50 & 7.00 & 6.25 & 0.17 \\
\hline 14 & 5.00 & 0.50 & 1.63 & 6.00 & 7.00 & 6.00 & 7.50 & 6.00 & 0.17 \\
\hline 15 & 5.00 & 0.75 & 1.63 & 8.50 & 8.25 & 7.00 & 8.50 & 8.00 & 0.27 \\
\hline 16 & 5.00 & 1.00 & 1.63 & 8.50 & 8.50 & 8.50 & 8.75 & 8.50 & 0.35 \\
\hline 17 & 6.00 & 0.90 & 2.00 & 8.25 & 7.50 & 9.00 & 8.50 & 8.50 & 0.41 \\
\hline 18 & 4.00 & 0.60 & 2.00 & 6.00 & 7.00 & 5.50 & 6.50 & 6.00 & 0.18 \\
\hline 19 & 5.00 & 0.75 & 1.63 & 8.00 & 8.50 & 7.25 & 8.25 & 8.25 & 0.27 \\
\hline 20 & 6.68 & 0.75 & 1.63 & 8.50 & 8.25 & 7.00 & 8.25 & 8.00 & 0.35 \\
\hline
\end{tabular}

${ }^{\#}$ Body(consistency); ${ }^{*}$ Colour and Appearance; ${ }^{\circledR}$ Overall Acceptability, The sensory scores are based on 9 Point Hedonic Scale

tin of Loba chemical, Mumbai and Iota carrageenan of Himedia Laboratories Pvt. Ltd., Mumbai were used as a stabilizer in buttermilk.

Preparation of Moringa pod buttermilk: The standardized milk was heated to $90{ }^{\circ} \mathrm{C}$ for $5 \mathrm{~min}$. The milk was inoculated with starter culture added @ $7 \mathrm{~g} / 100 \mathrm{~kg}$ milk and incubated at $40 \pm 2{ }^{\circ} \mathrm{C}$ till slightly less $(0.05 \%$ LA) than desired acidity in the curd ( 0.7 to $1.0 \% \mathrm{LA})$ was obtained. Dahi was stirred using a blender and immediately cooled to $7 \pm 2{ }^{\circ} \mathrm{C}$. The period spent for stirring cooling i.e. 25 to $30 \mathrm{~min}$. was enough to give final desired acidity in the curd.

Moringa base was prepared using calculated quantity of dry ingredients viz. stabilizer (pectin @ 0.04\% and carrageenan@0.015\%w/w, sugar@4\%, salt@0.5 \%, MPP@ 1 to $2.0 \%$. All the dry ingredients mixed and blended in potable water at 35-40 Cby stirring at 600 rpm (Yorko Micro Tissue Homogenizer, New Delhi). The quantity of water was calculated on the basis of required Total Milk Solids (TMS) in buttermilk (i.e. between 4.00 to $6.00 \%$ ). Finally, the Moringa base was blended with stirred dahi to prepare MPBM. The product was subjected to thermization at $65{ }^{\circ} \mathrm{C}$ for $5 \mathrm{~min}$. and cooled immediately to $10 \pm 2{ }^{\circ} \mathrm{C}$ and filled in clean and sanitized PET bottles $(250 \mathrm{ml})$ screw capped and stored at refrigeration temperatures (i.e. $7 \pm 2^{0} \mathrm{C}$ ).

Physico-chemical analysis: The experimental samples of buttermilks were analyzed for total solids (TS), protein, fat and ash as per methods advocated by Bureau of Indian standards (BIS 1989). Soluble nitrogen content was estimated by the method outlined by Kosikowaski (1982). Iron concentration of MPBM was estimated by atomic absorption spectrophotometry
(Spectrophotometer - Perkin Elmer model 3110), $1=$ $248.3 \mathrm{~nm}$. The calcium content of product was measured according to the method given by BIS (SP: 18 (Part XI) 1989). Vitamin A was analyzed using the standard procedure of AOAC (2004). Potassium content was analyzed by using the standard procedure of AOAC (2004). Vitamin C estimation was carried out by the procedure described as per BIS Hand Book (1989). The crude fibre content of buttermilk was determined by the method described in BIS Handbook (1989) using 2 g sample.

Microbiological analysis: For microbiological analysis (for lactobacilli, SPC, yeast and mold and coliforms) $11 \mathrm{~g}$ of sample was diluted in $99 \mathrm{ml}$ phosphate buffer according to the method described in IS: 1479 (1961). Further, serial dilutions were prepared in $9 \mathrm{ml}$ phosphate buffer. One ml each from two or three suitable dilutions was poured with either acidified MRS agar. The plates were allowed to solidify and then layered with 6-7 $\mathrm{ml}$ of the same agar. Number of colonies developed were counted after incubating plates at $37^{\circ}$ $\mathrm{C}$ for $48 \mathrm{~h}$ and expressed as colony forming units (cfu) of lactobacilli/g. The methods of plating, incubation and counting for the enumeration of Standard Plate Count (SPC), yeasts and molds as well as coliforms were followed as described by BIS (1989 (Part XI)).

Experimental design: The three factor Response Surface Methodology (RSM) with Central Composite Rotatable Design (CCRD) was used for designing the experimental combinations. The experiment was designed using software Design Expert version 10.0.2. The variables used were TMS ( $\% \mathrm{w} / \mathrm{w}$ of buttermilk), acidity of dahi (\% LA) and MPP (\% w/w of buttermilk) and level of these variables along with experi- 
Binjan K. Patel et al. / J. Appl. \& Nat. Sci. 9 (1): 466 - 475 (2017)

Table 3. Coefficient of the full second order polynomial model for coded sensory responses to different levels of ingredients for Moringa Pod Buttermilk.

\begin{tabular}{lccccccc}
\hline \multirow{2}{*}{ Terms } & & $\begin{array}{c}\text { Flavour } \\
\text { Score }\end{array}$ & \multirow{2}{*}{ Body Score } & $\begin{array}{c}\text { Acidity } \\
\text { Score }\end{array}$ & $\begin{array}{c}\text { Color and Ap- } \\
\text { pearance Score }\end{array}$ & $\begin{array}{c}\text { Overall Accepta- } \\
\text { bility Score }\end{array}$ & $\begin{array}{c}\text { Acidity } \\
\text { Value }\end{array}$ \\
\cline { 3 - 8 } & & \multicolumn{7}{c}{ (Out of 9) } \\
\hline Intercept & & 8.38 & 8.26 & 7.08 & 8.25 & 0.27 \\
Linear Lev- & $\mathrm{A}$ & $0.356959^{*}$ & $0.350303^{*}$ & -0.00666 & 0.172239 & $0.3378^{*}$ & $0.05215^{*}$ \\
el & $\mathrm{B}$ & $0.911958^{*}$ & $0.477613^{*}$ & $1.05840^{*}$ & $0.721414^{*}$ & $0.9120^{*}$ & $0.05585^{*}$ \\
& $\mathrm{C}$ & -0.1531 & -0.1348 & -0.06657 & -0.09153 & -0.0549 & 0.0001 \\
Interactive & $\mathrm{A}$ x B & 0.03125 & 0.125 & 0.09375 & 0.03125 & 0.0938 & 0.0175 \\
Effect & $\mathrm{A} \mathrm{x} \mathrm{C}$ & -0.03120 & 0.0001 & 0.09375 & -0.09376 & -0.0312 & 0.0001 \\
& $\mathrm{~B}$ x C & 0.09375 & $-0.375^{*}$ & 0.28125 & 0.09370 & 0.0938 & 0.0001 \\
Quadratic & $\mathrm{A}^{2}$ & $-0.46758^{*}$ & $-0.43158^{*}$ & 0.06340 & -0.22116 & $-0.3931^{*}$ & -0.00014 \\
Level & $\mathrm{B}^{2}$ & $-0.42338^{* *}$ & $-0.21061^{* *}$ & 0.06338 & -0.04439 & $-0.3048^{*}$ & -0.00544 \\
$\mathrm{R}^{2}$ & $\mathrm{C}^{2}$ & -0.15822 & $-0.29899^{*}$ & 0.06332 & $-0.26536^{* *}$ & $-0.2164^{* *}$ & 0.008701 \\
Model F-value & & 0.8787 & 0.8951 & 0.9026 & 0.8353 & 0.9346 & 0.9743 \\
APV & 8.05 & 9.49 & 10.30 & 5.64 & 15.88 & 42.13 \\
Suggested Model & 8.53 & 9.83 & 12.01 & 8.49 & 12.70 & 22.62 \\
\hline
\end{tabular}

*: $\mathrm{P} \leq 0.01$; *: $\mathrm{P} \leq 0.05$; ns: non-significant; $\mathrm{APV}=$ Adequate Precision Value; $\mathrm{R}^{2}=$ Coefficient of determination; $\mathrm{A}, \mathrm{B}$ and $\mathrm{C}$ refer to the Total Milk solids, Acidity of Dahi and Moringa Pod Powder respectively.

mental plan consisting of three variables at five levels and six replicates at center point. The variables were standardized to simplify computation and to deduce the relative effect of variables on response. The magnitude of the coefficients in second order polynomial shows the effect of that variable on the response. The factors (independent variables) and their levels, in terms of coded and decoded forms are given in Table 1. The experimental plan consisted of a set of twenty experiments

Sensory evaluation: The Moringa buttermilk was analyzed for sensory characteristics by a panel of ten semi trained judges using 9-point hedonic scale. The products were judged for flavour, body (consistency), colour and appearance, acidity score and overall acceptability.

Statistical analysis: Statistical analysis of data was carried out using Completely Randomized Design (Steel and Torrie 1980) and RSM. The experiment was designed and responses were analyzed using software Design Expert version 10.0.2.

\section{RESULTS AND DISCUSSION}

In the present study, level of TMS ranging from 4 to 8 $(\%)$ was selected based on results of preliminary trials. Similarly the level of acidity of dahi was selected based on preliminary trials taken for MPBM, which ranged from 0.60 to 0.90 (\% LA) and MPP from 1.25 to $2.00(\%)$. In this investigation the level of TMS, acidity of dahi and MPP were optimized using CCRD and RSM consisting 20 experiments as shown in Table 2 were evaluated for sensory and physico-chemical characteristics.

Effect of different levels of Moringa Pod Powder, TMS and acidity of dahi on sensory properties and physico-chemical attributes of Moringa Pod Buttermilk: The flavour, body (consistency), acidity score, color and appearance and overall acceptability score of MPBM was observed in the range from 5.75-8.50, 6.00

Table 4. Predicted sensory scores of optimized Moringa Pod Buttermilk from RSM analysis.

\begin{tabular}{llllll}
\hline Solution No. & $\begin{array}{l}\text { Flavour } \\
\text { Score* }\end{array}$ & $\begin{array}{l}\text { Body (consistency) } \\
\text { Score* }\end{array}$ & $\begin{array}{l}\text { Acidity } \\
\text { Score }\end{array}$ & $\begin{array}{l}\text { Colour and Appear- } \\
\text { ance Score* }\end{array}$ & $\begin{array}{l}\text { Overall Acceptabil- } \\
\text { ity Score* }\end{array}$ \\
\hline 1 & 8.77 & 8.07 & 8.53 & 8.76 & 8.73 \\
\hline
\end{tabular}

* Sensory scores obtained on 9 point hedonic scale

Table 5. Comparison of predicted v/s actual values of responses selected for MPBM.

\begin{tabular}{|c|c|c|c|c|c|}
\hline Response & P Value & Predicted Value ${ }^{*}$ & Actual Value ${ }^{(a)}$ & Cal. t-Value ${ }^{\#}$ & Significance \\
\hline Flavour $^{1}$ & 0.9512 & 8.33 & 8.34 & 0.0651 & $\mathrm{NS}$ \\
\hline Body (consistency) ${ }^{1}$ & 0.2053 & 8.35 & 8.22 & 1.5112 & NS \\
\hline Acidity Score $^{1}$ & 0.1404 & 8.40 & 8.24 & 1.8353 & NS \\
\hline Colour\& Appearance ${ }^{1}$ & 0.7209 & 8.12 & 8.17 & 0.3834 & NS \\
\hline Overall acceptability ${ }^{1}$ & 0.9100 & 8.12 & 8.14 & 0.1204 & NS \\
\hline Acidity(per cent LA) & 0.6213 & 0.37 & 0.364 & 0.5345 & NS \\
\hline
\end{tabular}

${ }^{1}$ Sensory score on 9 point hedonic scale; * Predicted values of Design Expert 9.0.3.1 package; @ Actual values are average of five trials for optimized product; \# t-values found non-significant at 5 per cent level of significance; NS = Non-significant; Tabulated $\mathrm{t}$-value $=2.776$ (Cal. $\mathrm{t}$-value less than tabulated value). 
Binjan K. Patel et al. / J. Appl. \& Nat. Sci. 9 (1): 466 - 475 (2017)

Table 6. Changes in sensory scores of Moringa Pod Buttermilk stored at $7 \pm 2{ }^{\circ} \mathrm{C}$.

\begin{tabular}{|c|c|c|c|c|c|c|c|}
\hline \multirow{2}{*}{ Treatments $(\mathrm{T})$} & \multicolumn{6}{|c|}{ Storage period in days $(\mathrm{P})$} & \multirow{2}{*}{$\begin{array}{l}\text { Average for } \\
\text { Treatment (T) }\end{array}$} \\
\hline & 0 & 5 & 10 & 15 & 20 & 25 & \\
\hline \multicolumn{8}{|l|}{ Flavour Score } \\
\hline Control & $8.52 \pm 0.13$ & $7.72 \pm 0.10$ & $6.82 \pm 0.08$ & $6.15 \pm 0.05$ & $5.52 \pm 0.08$ & $4.33 \pm 0.42$ & 6.51 \\
\hline MPBM & $8.22 \pm 0.11$ & $8.07 \pm 0.06$ & $7.97 \pm 0.06$ & $7.87 \pm 0.06$ & $7.77 \pm 0.06$ & $6.35 \pm 0.10$ & 7.71 \\
\hline Average for & & & & & & & \\
\hline Period(P) & 8.37 & 7.89 & 7.39 & 7.01 & 6.64 & 5.34 & \\
\hline $\mathrm{CD}(0.05)$ & \multicolumn{7}{|c|}{$\mathrm{T}=0.09 ; \mathrm{P}=0.12 ; \mathrm{TxP}=0.21$} \\
\hline \multicolumn{8}{|c|}{ Body (Consistency) Score } \\
\hline Control & $8.37 \pm 0.15$ & $7.83 \pm 0.15$ & $7.67 \pm 0.21$ & $7.47 \pm 0.12$ & $7.17 \pm 0.15$ & $6.87 \pm 0.06$ & 7.56 \\
\hline MPBM & $8.18 \pm 0.05$ & $8.07 \pm 0.06$ & $7.97 \pm 0.06$ & $7.87 \pm 0.06$ & $7.73 \pm 0.06$ & $7.30 \pm 0.10$ & 7.86 \\
\hline Average for & & & & & & & \\
\hline Period(P) & 8.28 & 7.95 & 7.82 & 7.67 & 7.47 & 7.08 & \\
\hline $\mathrm{CD}(0.05)$ & \multicolumn{7}{|c|}{$\mathrm{T}=0.07 ; \mathrm{P}=0.11 ; \mathrm{TxP}=0.18$} \\
\hline \multicolumn{8}{|c|}{ Colour and Appearance Score } \\
\hline Control & $8.30 \pm 0.17$ & $8.19 \pm 0.14$ & $8.07 \pm 0.11$ & $7.95 \pm 0.09$ & $7.84 \pm 0.07$ & $7.72 \pm 0.05$ & 8.01 \\
\hline MPBM & $8.15 \pm 0.02$ & $8.07 \pm 0.06$ & $7.98 \pm 0.07$ & $7.89 \pm 0.08$ & $7.80 \pm 0.10$ & $7.64 \pm 0.16$ & 7.92 \\
\hline Average for & & & & & & & \\
\hline Period(P) & 8.23 & 8.13 & 8.02 & 7.92 & 7.82 & 7.68 & \\
\hline $\mathrm{CD}(0.05)$ & \multicolumn{7}{|c|}{$\mathrm{T}=0.07 ; \mathrm{P}=0.10 ; \mathrm{TxP}=0.17$} \\
\hline \multicolumn{8}{|l|}{ Acidity Score } \\
\hline Control & $8.42 \pm 0.03$ & $7.72 \pm 0.10$ & $6.82 \pm 0.08$ & $6.15 \pm 0.05$ & $5.52 \pm 0.08$ & $4.33 \pm 0.42$ & 6.49 \\
\hline MPBM & $8.20 \pm 0.05$ & $8.07 \pm 0.06$ & $7.97 \pm 0.06$ & $7.87 \pm 0.06$ & $7.75 \pm 0.09$ & $6.35 \pm 0.10$ & $8.20 \pm 0.05$ \\
\hline Average for & & & & & & & \\
\hline Period(P) & 8.31 & 7.89 & 7.39 & 7.01 & 6.63 & 5.34 & \\
\hline $\mathrm{CD}(0.05)$ & \multicolumn{7}{|c|}{$\mathrm{T}=0.08 ; \mathrm{P}=0.12 ; \mathrm{TxP}=0.20$} \\
\hline \multicolumn{8}{|c|}{ Overall Acceptability Score } \\
\hline Control & $8.15 \pm 0.05$ & $7.75 \pm 0.05$ & $6.82 \pm 0.08$ & $6.15 \pm 0.05$ & $5.52 \pm 0.08$ & $4.33 \pm 0.42$ & 6.45 \\
\hline MPBM & $8.16 \pm 0.04$ & $8.11 \pm 0.02$ & $7.97 \pm 0.06$ & $7.87 \pm 0.06$ & $7.77 \pm 0.06$ & $6.35 \pm 0.10$ & 7.70 \\
\hline \multicolumn{8}{|l|}{ Average for } \\
\hline Period(P) & 8.15 & 7.93 & 7.39 & 7.01 & 6.64 & 5.34 & \\
\hline $\mathrm{CD}(0.05)$ & \multicolumn{7}{|c|}{$\mathrm{T}=0.08 ; \mathrm{P}=0.12 ; \mathrm{TxP}=0.20$} \\
\hline
\end{tabular}

$-8.50, \quad 5.50-9.00,6.50-9.00,6.00-8.50$ (out of 9) respectively. The scores for physico-chemical response (acidity) varied from 0.17 to $0.41 \%$ LA. The coefficient of determination $\left(\mathrm{R}^{2}\right)$ shown in Table 3 reflects the proportion of variability in data explained or accounted by the model for flavour, body, acidity score, $\mathrm{C}$ and $\mathrm{A}$ and $\mathrm{OA}$ were $0.8787,0.8951,0.9026$, 0.8353 and 0.9346 respectively. A larger $R^{2}$ values $(>0.87)$ is statistically adequate for developing a model or equation. The probability value $(\mathrm{P})$ showed the adequacy of the models so used to describe the effect of variables on different responses. The effect of TMS ( $\%$ w/w of MPBM), acidity of dahi (\% LA) and MPP (\% $\mathrm{w} / \mathrm{w}$ of MPBM) on the responses is shown in Table 3. The sign and magnitude of coefficients indicate the effect of the variable on the responses. The total effect of individual variable and combined effect of the variables at all levels are presented in Table 3 .

Flavour score: The flavour score of MPBM ranged from 5.75 to 8.5 on 9 point hedonic scale. TMS and acidity of dahi showed it's significant $(\mathrm{P}<0.01)$ positive effect on flavour score, whereas the MPP had nonsignificant $(\mathrm{P}>0.05)$ effect on flavour score at linear level. TMS and acidity of dahi showed significant $(\mathrm{P}<0.05)$ negative effect at quadratic level, while MPP had non-significant $(\mathrm{P}>0.5)$ negative effect at quadratic level on the flavour scores.

Body (consistency) score: The body (consistency) scores of MPBM indicated variation from 6 to 8.5 (out of 9). The study indicated a significant $(\mathrm{P}<0.05)$ positive effect of level of TMS and acidity of dahi on the body (consistency) score. MPP had a non-significant positive effect on body (consistency) score and at quadratic level it had a significant $(\mathrm{P}<0.01)$ negative effect.

Acidity score: The values of acidity score ranged from 5.5 to 9 on 9 point hedonic scale. Significant positive $(\mathrm{P}<0.01)$ effect of level of TMS and acidity of dahi was observed on the acidity score. MPP and TMS had a non-significant $(\mathrm{P}>0.05)$ negative effect on acidity score and at quadratic level it has a significant $(\mathrm{P}<0.05)$ positive effect. The interaction effect of all three variables was found to be positive.

Colour and appearance score: The colour and appearance scores of MPBM showed variation from 6.5 to 9 (out of 9 ). P values of acidity of dahi showed its significance $(\mathrm{P}<0.01)$ in linear terms. The positive sign indicated the positive effect of the TMS and negative sign indicated negative effect of MPP on the colour and appearance score. TMS and acidity of dahi showed non-significant $(\mathrm{P}>0.05)$ negative effect at quadratic level. A significant $(\mathrm{P}<0.05)$ negative effect on colour 
and appearance was found with the higher level of $\operatorname{MPP}\left(\mathrm{C}^{2}\right)$.

Overall acceptability score: The overall acceptability scores of MPBM ranged from 6.0 to 8.5 on 9 point hedonic scale. TMS, acidity of dahi and MPP showed its significance $(\mathrm{P}<0.01)$ in linear terms. The negative sign indicates the negative effect of MPP on the overall acceptability score. Also at extremely higher levels of TMS and acidity of dahi, overall acceptability scores decreased; both had a significant $(\mathrm{P}<0.01)$ positive effect on the overall acceptability of MPBM. MPP had a significant $(\mathrm{P}<0.05)$ desirable effect on overall acceptability score and at quadratic level it has a significant $(\mathrm{P}<0.05)$ negative effect.

The response surface plot for the values obtained is shown in Fig 1 which is based on the above model with varying levels of the two variables (TMS and Acidity of dahi) studied within the experimental range. The values presented in Table 3 revealed that when TMS and acidity of dahi was increased in MPBM, it affected the overall acceptability score by increasing it significantly $(\mathrm{P}<0.01)$, the effect being higher but negative on increased additions. The MPP had nonsignificant $(\mathrm{P}>0.05)$ effect on overall acceptability score but negative significant $(\mathrm{P}<0.05)$ effect on increased additions. No data are reported in the literature on effect of TMS, acidity of dahi and MPP on colour and appearance of MPBM.

Acidity (\% LA): The values of acidity ranged from 0.17 to $0.41 \%$ LA in MPBM. P value for TMS and acidity of dahi were positively significant $(\mathrm{P}<0.01)$ in linear terms. Positive sign for the values indicates the positive effect of TMS and acidity of dahi on values of acidity (\% LA) in MPBM. A non-significant $(\mathrm{P}>0.05)$ positive effect was observed with higher level of TMS and acidity of dahi and similar negative effect with MPP at quadratic level.

Optimization of product formulation for Moringa Pod
Buttermilk: Process optimization for the development of Moringa Pod Buttermilk was carried out with the objective of determining the best possible combination (s) of different levels of factors viz. TMS (\%), Acidity of dahi (\% LA) and MPP (\%) that would lead to the most acceptable product in terms of sensory scores, compositional and physico-chemical attributes. The goals for all sensory responses were set to be maximized and overall acceptability was given higher importance level i.e. 4 than other responses.

The final product was manufactured employing suggested formulation and the actual results were obtained from the MPBM manufacture. The predicted values of the criteria/responses selected for optimization under study were compared with the actual values of the selected responses. The results obtained confirmed that the selected combination, $5.60 \%$ TMS, $0.90 \%$ acidity of dahi, $1.92 \%$ MPP and $0.32 \%$ acidity of MPB was the best one in terms of the sensory and physico-chemical compositional responses delineated at the beginning of the study and the results were also validated statistically (Table 5).

The predicted compositional and physico-chemical attributes of optimized MPBM from RSM analysis put forward the most appropriate solution that was optimized by the software consisted of $5.60 \%$ TMS, 0.90 $\%$ acidity of dahi, $1.92 \%$ MPP and $0.32 \%$ acidity of MPBM having desirability 0.836 . The predicted sensory scores, physico-chemical parameters viz. flavour, body, acidity score, colour and appearance, overall acceptability and acidity of product from RSM analysis are depicted in Table 4 . The final product was manufactured employing this suggested that formulation and the actual results were obtained from the manufacture of Moringa Pod Buttermilk. The predicted values of the criteria/responses selected for process optimization under study were compared with the actual values of the selected responses. The results obtained con-

Table 7. Changes in microbiological counts and acidity Moringa Pod Buttermilk during Storage.

\begin{tabular}{|c|c|c|c|c|c|c|c|}
\hline \multirow{2}{*}{ Treatments $(\mathbf{T})$} & \multicolumn{6}{|c|}{ Storage period in days $(P)$} & \multirow{2}{*}{$\begin{array}{l}\text { Average for } \\
\text { Treatment (T) }\end{array}$} \\
\hline & 0 & 5 & 10 & 15 & 20 & 25 & \\
\hline \multicolumn{8}{|l|}{ LAB Count (log cfu/g) } \\
\hline Control & $4.48 \pm 0.02$ & $4.45 \pm 0.03$ & $4.40 \pm 0.02$ & $4.43 \pm 0.02$ & $4.56 \pm 0.03$ & $4.61 \pm 0.03$ & 4.49 \\
\hline МРВМ & $4.41 \pm 0.02$ & $4.46 \pm 0.02$ & $4.36 \pm 0.02$ & $4.34 \pm 0.02$ & $4.48 \pm 0.02$ & $4.56 \pm 0.02$ & 4.44 \\
\hline \multicolumn{8}{|l|}{ Average for } \\
\hline Period(P) & 4.45 & 4.45 & 4.38 & 4.39 & 4.52 & 4.58 & \\
\hline CD (0.05) & \multicolumn{7}{|c|}{$\mathrm{T}=\mathbf{0 . 0 1} ; \mathrm{P}=\mathbf{0 . 0 2} ; \mathrm{TxP}=\mathbf{0 . 0 3}$} \\
\hline \multicolumn{8}{|l|}{ SPC (log cfu/g) } \\
\hline Control & $4.26 \pm 0.02$ & $4.33 \pm 0.02$ & $4.38 \pm 0.04$ & $4.45 \pm 0.04$ & $4.48 \pm 0.03$ & $4.52 \pm 0.03$ & 4.40 \\
\hline МРВМ & $4.15 \pm 0.02$ & $4.23 \pm 0.03$ & $4.32 \pm 0.04$ & $4.37 \pm 0.04$ & $4.40 \pm 0.03$ & $4.45 \pm 0.04$ & 4.32 \\
\hline Average for Period(P) & 4.20 & 4.28 & 4.35 & 4.41 & 4.44 & 4.49 & \\
\hline \multicolumn{8}{|c|}{$\mathrm{CD}(0.05) \quad \mathrm{T}=0.02 ; \mathrm{P}=0.03 ; \mathrm{T} \times \mathrm{P}=0.05$} \\
\hline \multicolumn{8}{|c|}{ Acidity (per cent LA) } \\
\hline Control & $0.33 \pm 0.01$ & $0.36 \pm 0.01$ & $0.41 \pm 0.02$ & $0.51 \pm 0.01$ & $0.60 \pm 0.01$ & $0.64 \pm 0.01$ & 0.47 \\
\hline МРВM & $0.36 \pm 0.01$ & $0.40 \pm 0.01$ & $0.43 \pm 0.02$ & $0.45 \pm 0.02$ & $0.47 \pm 0.01$ & $0.51 \pm 0.02$ & 0.44 \\
\hline \multicolumn{8}{|l|}{ Average for } \\
\hline Period(P) & 0.35 & 0.38 & 0.42 & 0.48 & 0.54 & 0.57 & \\
\hline CD (0.05) & \multicolumn{7}{|c|}{$T=0.01 ; P=0.02 ; T \times P=0.03$} \\
\hline
\end{tabular}


Binjan K. Patel et al. / J. Appl. \& Nat. Sci. 9 (1): 466 - 475 (2017)

Table 8. Comparison of proximate composition and \% DV of Moringa pod buttermilk with control.

\begin{tabular}{lcccc}
\hline Components (Unit) & Control $^{(}$ & \% DV & MPBM & \% DV \\
\hline Total solids $(\mathrm{g} / 100 \mathrm{~g})$ & 5.91 & - & 11.77 & - \\
Fat $(\mathrm{g} / 100 \mathrm{~g})$ & 1.5 & - & 1.84 & - \\
Protein $(\mathrm{g} / 100 \mathrm{~g})$ & 1.7 & - & 1.51 & - \\
Ash $(\mathrm{g} / 100 \mathrm{~g})$ & 0.41 & - & 0.89 & - \\
Total Carbohydrate & 2.3 & - & 5.82 & - \\
Added Sugar & 0 & - & 3.74 & - \\
Total Dietary Fiber $(\mathrm{g} / 100 \mathrm{~g})$ & 0 & 0 & 0.63 & 6.35 \\
Vitamin C (mg/100g) & 1.07 & 5.4 & 1.7 & 8.50 \\
Vitamin A (mcg/100 g) & 60 & 3.6 & 79.97 & 5.00 \\
Calcium (mg/100 g) & 50 & 15 & 70 & 21 \\
Iron $(\mathrm{mg} / 100 \mathrm{~g})$ & 0.17 & 2.83 & 0.59 & 10 \\
Potassium $(\mathrm{mg} / 100 \mathrm{~g})$ & 50 & 4.29 & 100 & 8.57 \\
Energy (kcal/100g) & 29.3 & & 37.66 & \\
\hline
\end{tabular}

\# Values represents mean of duplicates; ${ }^{@}$ AmulMasti spiced buttermilk; * \%DV (300g serving size) calculated based upon a caloric intake of 2,000 calorie $(8400 \mathrm{~kJ})$, for adults and children four or more years of age.

firm that the selected combination is the best one in terms of the sensory, compositional and textural responses delineated at the beginning of the study. The results are also validated statistically by ' $t$ ' test. The values for ' $t$ ' test being less than the table values, it is inferred that there is no significant $(\mathrm{P}>0.05)$ difference between the predicted and actual values of responses are shown in Table 5.

Standardized method for manufacture of Moringa pod buttermilk: The manufacture of MPBM by standardized method was done in two parts. In the first part, Moringa pod base was prepared by weighing the required amount of dried ingredients viz. MPP @ 1.92 \%, pectin@0.04\%, carrageenan@0.015\%, sugar@ $4.0 \%$, salt@0.5\%, spice mixture@0.49\%. All the dried ingredients were calculated on the basis of w/w of buttermilk. Calculated amount of potable water (45 to $50{ }^{\circ} \mathrm{C}$ ) to lower down TMS of dahi from $13.0 \%$ to $5.60 \%$ was taken in a SS vessel. The dry ingredients were added to the water and blended in high speed blender for $2 \mathrm{~min}$ and heated to $90{ }^{\circ} \mathrm{C} / \mathrm{no}$ hold followed by immediate cooling to room temperature (35$40{ }^{\circ} \mathrm{C}$ ). In the second part of the procedure SPM was taken, then it was pre heated to $35-40{ }^{\circ} \mathrm{C}$, filtered, heated to $90{ }^{\circ} \mathrm{C}$ for $5 \mathrm{~min}$, cooled to $40 \pm 2{ }^{\circ} \mathrm{C}$ and incubated with DVS lactic mesophilic/ thermophilic dahi culture (@0.7g/10 kg milk) till an acidity of $0.85 \%$ LA) was attained. The curd was broken and cooled immediately to $8 \pm 2{ }^{\circ} \mathrm{C}$. After cooling the curd attained the desired final acidity of $0.90 \%$ LA. The Moringa pod base was added to the dahi and blended for 30-40 $\mathrm{S}$ in a mixer at low speed. Finally, for proper blending product was heated to $60{ }^{\circ} \mathrm{C}$ and subjected to low pressure homogenization at $25 \mathrm{~kg} / \mathrm{cm}^{2}$ followed by thermization at $65{ }^{\circ} \mathrm{C}$ for $5 \mathrm{~min}$ and filling in pre sterilized PET bottles and stored at $7 \pm 2{ }^{\circ} \mathrm{C}$.

Storage studies: Various physico-chemical changes occurring in MPBM and Control were monitored at predetermined time intervals (on every $5^{\text {th }}$ day of storage) till the product was rejected on sensory ground (when the score reaches 6.0 or less on hedonic scale) or till it became unacceptable. Control (C) was prepared by addition of water at the rate of $30 \%$ in dahi, followed by mixing and addition of salt @ 0.5\% and roasted cumin@0.4\% following the method of Maheta et al. 2014.

Changes in sensory scores during storage: The most affected sensory attribute is flavour. The changes in flavour score during storage of control and MPBM are presented in Table 6 . The initial flavour scores of the two different type of buttermilk viz. Control and MPBM were 8.52 and 8.22 respectively. In case of Control, the flavour score decreased from the initial value of $8.52 \pm 0.13$ to $7.72 \pm 0.10$ (on the $5^{\text {th }}$ day) and further decreased to $6.35 \pm 0.10$ (on the $20^{\text {th }}$ day) and on which the judging panel rejected it. The pertinent statistical analysis revealed that type of buttermilk as well as storage period had significant $(\mathrm{P}<0.05)$ effect on the flavour scores of buttermilk. The interaction between type of buttermilk (T) and storage period (P) was statistically significant $(\mathrm{P}<0.05)$ for changes in flavour score of buttermilk over the storage period. Moreover, the difference in flavour score of the butter milk prepared with Moringa (MLBM) remained significantly $(\mathrm{P}<0.05)$ higher compared to $\mathrm{C}$. In case of buttermilks containing Moringa, the flavour scores were found acceptable even on the $25^{\text {th }}$ day of storage. The samples were noticed to develop slight staleness and slight ethereal smell on the $25^{\text {th }}$ day of storage, hence the study was discontinued. The changes in flavour score of the buttermilk during storage revealed that the MLBM was acceptable even on the $25^{\text {th }}$ day of storage, indicating its better stability compared to Control buttermilk. The reason for sharp decrease in flavour score of the Control buttermilk was attributed to lower intensity of desirable flavour and higher acidity. However, no research has been reported in the literature on the changes in flavour scores in Moringa buttermilk during storage for comparison.

There was significant $(\mathrm{P}<0.05)$ difference observed in 
body scores of Control and MPBM. In Moringa buttermilk with body and texture score was slightly lower than Control throughout the storage period. The decrease in body and texture score of the buttermilks might be attributed to physicochemical changes taking place in the product during the storage. It is reported that buttermilk typically has a thick, homogeneous body. Some of the known culture-related defects will eventually lead to body and texture defects. For example, if the culture lacks adequate activity and if the product is cooled at low acidity, the finished product will not have optimum viscosity. Some contaminants produce slime, which results in a highly viscous product (Mistry 2001). Therefore, reduction in body score of buttermilks may be attributed to such reasons as discussed above. However, no research has been reported in the literature on the changes in body scores in Moringa buttermilk during storage for comparison.

Significant difference $(\mathrm{P}<0.05)$ in colour and appearance score in both the products was found during the storage of $25^{\text {th }}$ day. The score significantly $(\mathrm{P}<0.05)$ decreased on $5^{\text {th }}, 10^{\text {th }}, 15^{\text {th }}$ and $20^{\text {th }}$ day of storage. Thereafter, the decrease in colour and appearance score was significant $(\mathrm{P}<0.05)$. The interaction effect of the treatments with the period showed significant $(\mathrm{P}<0.05)$ difference in the scores. The decrease in colour score may be due to the degradation of chlorophyll during the storage. The decrease in colour and appearance score of the buttermilk might be attributed to associated physicochemical changes taking place in product during storage. However, no research has been reported in the literature on the changes in colour and appearance scores in Moringa buttermilk during storage for comparison.

In case of Control, the acidity score decreased from the initial value of $8.42 \pm 0.13$ to $7.72 \pm 0.10$ (on the $5^{\text {th }}$ day) and further decreased to $5.52 \pm 0.08$ (on the $20^{\text {th }}$ day) and on which the judging panel rejected it. The changes in acidity score of the buttermilk during storage revealed that the MPBM was acceptable even on the $25^{\text {th }}$ day of storage, indicating its better stability compared to Control buttermilk ( $15^{\text {th }}$ day). The reason for sharp decrease in acidity score of the Control buttermilk was attributed to progressive decrease in $\mathrm{pH}$ and increase in acidity during storage. However, no research has been reported in the literature on the changes in acidity scores in Moringa buttermilk during storage for comparison.

There was significant $(\mathrm{P}<0.05)$ decrease observed in overall acceptability score during the storage. The $0 \mathrm{~d}$ score decreased from 8.15 and 8.26 out of 9.00 for the Control, MPBM, 8.16 to 7.77 respectively on the $20^{\text {th }}$ day of storage. The decrease in score was found to be significant $(\mathrm{P}<0.05)$ for the products. The significant difference in score obtained from $0 \mathrm{~d}$ to 10 day of storage in control whereas non-significant for the Moringa product. The interaction effect of the treatments with the period also showed significant $(\mathrm{P}<0.05)$ changes. The overall acceptability of MPBM was statistically superior. Hence there was no such difference observed in acceptability due to addition of type of Moringain the fermented product. The main reason for sharp decrease in overall acceptability score of the buttermilks with was attributed to deterioration of flavour. The other reason was undesirable changes in body of the product.

According to sensory profile, the Moringa product was better or at par in terms of different attribute throughout the storage period compared to control. Based on the sensory attributes studied during storage, Moringa buttermilk showed a slight improvement in terms of acceptability compared to control during storage. It can be concluded from this Section that $\mathrm{C}$ had a shelf life of 15 days whereas MPBM had a shelf life of 25 days when stored in PET bottles, the improvement in shelf life in Moringa buttermilk could be attributed to the significant reduction in SPC count (Table 7) in MPBM compared to control during the entire storage period.

The increased shelf life in Moringa buttermilk could also be attributed to the antioxidant and anti-bacterial properties of Moringa. Nadeem et al. (2013) evaluated the antioxidant potential of an extract of Moringa oleifera for the stabilization of butter at refrigeration temperature and suggested that LEMO at $600 \mathrm{ppm}$ may be used for reasonable storage stability of butter at refrigeration temperature with acceptable sensory characteristics. Vanajakshi et al. (2015) found that fermented beverage containing Moringa had showed antibacterial activity and also exhibited radical scavenging activity. Therefore, the results obtained in this study are in accordance with those reported in literature as discussed above (Nadeem et al., 2013 and Vanjakshi et al. (2015). However, no research has been reported in the literature on the shelf life of Moringa buttermilk during storage for comparison.

Changes intitratable acidity during storage: The changes in titratable acidity (\% LA) of control (C) and MPBM stored at refrigerated temperature are presented in Table 7. During refrigerated storage, titratable acidity gradually increased from 0.33 to $0.64 \%$ LA in control whereas 0.36 to $0.51 \%$ in MPBM. There was a significant $(\mathrm{P}<0.05)$ increase in acidity during storage. Comparing the treatment and period means, control and Moringa buttermilk showed significant $(\mathrm{P}<0.05)$ increase in titratable acidity till $25^{\text {th }}$ day of storage. However, significant $(\mathrm{P}<0.05)$ increase in acidity was found up to $10^{\text {th }}$ day against the fresh or $0 \mathrm{~d}$. The interaction effect of the treatments with the period showed statistically significant $(\mathrm{P}<0.05)$ changes.

The progressive increase in titratable acidity during storage may be due to increase in number of organisms and the use of sugar in the experimental samples. Maheta et al. (2014) reported an increase in acidity in 
buttermilk samples during storage at refrigeration temperatures from an initial value of $0.60 \%$ LA to $0.79 \%$ LA on $12^{\text {th }}$ day of storage. Therefore, the results are in line of this study that titratable acidity increase during the refrigerated storage period. The differences in acidity could be attributed to the differences in the initial acidity of dahi as well as ingredients used in the products. However, no research has been reported in the literature on the changes in acidity of Moringa buttermilk during storage for comparison.

Changes in microbiological counts during storage: The changes in Lactobacilli count of control (C) and MPBM stored at refrigeration temperature are illustrated in Table 7. Lactobacilli count was significantly higher $(\mathrm{P}<0.05)$ in MPBM $(4.41 \mathrm{Log} \mathrm{cfu} / \mathrm{g})$ as compared to control $(4.48 \log \mathrm{cfu} / \mathrm{g})$ in the fresh product on 0 day. The viable count for control and MPBM were 4.61 and $4.56 \log \mathrm{cfu} / \mathrm{g}$ at the end of refrigeration storage. The LAB counts of buttermilk stored at $7 \pm 2^{\circ} \mathrm{C}$ delineated in Table 7 , indicates spasmodic changes in count during storage of chhash. Statistically there was significant $(\mathrm{P}<0.05)$ difference in LAB count throughout the storage period. The interaction effect of the treatments with the period also showed significant $(\mathrm{P}<0.05)$ changes. However, the Lactobacilli count $4.41 \log \mathrm{cfu} / \mathrm{g}$ vs $4.48 \mathrm{log} \mathrm{cfu} / \mathrm{g}$ for control, was appreciably lower in MPBM by the anti-bacterial effect of Moringa till the end of 25 day storage.

In case of experimental samples, the count remained almost stationary for some time (up to $10^{\text {th }}$ day of storage), which may be attributed to the damage caused by the heat treatment given to experimental buttermilks. The increase in LAB population during extended period of storage may be ascribed to repair of the damaged cells and their subsequent growth or other lactic organisms (other than culture organism) surviving the heat shock given to buttermilk or may also be due to diauxic growth phenomena (Stainier et al., 1985).

The SPC of buttermilk was significantly $(\mathrm{P}<0.05)$ influenced by storage period. During storage of buttermilks at refrigerated temperature also, a significant $(\mathrm{P}<0.05)$ increase in SPC was observed up to $25^{\text {th }}$ day of storage for Moringa buttermilk and $20^{\text {th }}$ day for C and thereafter, the product was found unacceptable due to rejection by sensory panel. However, no research has been reported in the literature on the changes in SPC count of Moringa buttermilk during storage for comparison.

Compositional analysis of Moringa pod buttermilk: According to guidelines provided by FDA (2013) on food labeling, the product label must include $\%$ daily value $(\% \mathrm{DV})$, to designate both the daily reference value (DRV) and recommended daily intake (RDI). The DV (\%) of control and MPBM (300 g serving size) was calculated. The proximate composition of $\mathrm{DV} \%$ of the product for various nutrients is presented in Table 8. In order to make a "good source of micro- nutrient", the finished product must ideally contain 10 to $19 \%$ of DV per serving. One serving size (300 g) per day of MPBM could be an "excellent source of calcium" having 21 per cent DV. MPBM had highest levels of fibre, providing 6.35 per cent DV from amongst both samples. Moreover, the product contains considerable amount Vitamin C (9\% DV) and protein $(8.5 \% \mathrm{DV})$. Therefore, this study was successful to formulate a composite fermented buttermilk which can be labeled as "good source of iron, protein, potassium and vitamin $\mathrm{A}$ " with considerable amount of vitamin $\mathrm{C}$ and potassium.

Consumer response study: The commercial success of any new product developed depends on the consumer response. Consumer response studies play a key role in launching a newly developed product in the market. Therefore, the MPBM manufactured using the recipe formulated in the present study was evaluated through a consumer survey conducted by selecting randomly 100 consumers representing different segments of the society. For consumer acceptance trial in the present project, the product was packed in $100 \mathrm{ml}$ PET Bottles and distributed to 100 probable consumers. The consumers were asked to indicate whether they like the product or not, and if yes, to what level i.e. "Excellent", "Very Good" or "Good". None of the consumers disliked the product.

In case of MPBM, none of the consumers disliked the product. It can be seen from Fig. 2, out of 100 consumers who judged the product 20 consumer rated it as excellent, 39 consumers rated it as very good and 41 consumers per cent rated it as good. This indicates that the products have a good potential for marketing. This indicates that the product has a good potential for marketing. The consumers, in general commented that such a product if available in the market would enormously benefit those who are health conscious, calorie conscious and those suffering from lifestyle diseases.

\section{Conclusion}

A method was standardized for manufacture of buttermilk containing Moringa pod powder as an ingredient. Based upon the results, conclusively, the product may be characterized as excellent source of calcium (21\% DV) and good source of protein $(8.5 \% \mathrm{DV})$ and potassium $(8.57 \% \mathrm{DV})$. Based on consumer response studies, the developed product has a good potential for marketing. The shelf-life of the product was 20 days when packaged in Polyethylene terephthalate (PET) bottles and stored under refrigeration $\left(7 \pm 2{ }^{\circ} \mathrm{C}\right)$ compared to 15 days for control buttermilk prepared without Moringa pod powder.

\section{REFERENCES}

AOAC Official methods of analysis (2004). 13th edition; Association of official analytical chemists, Washington DC. 
BIS Handbook of food analysis (1989). SP: 18 (Part XI Dairy Products). Bureau of Indian Standards, Manak Bhavan, Bahadur Shah Zafar Marg, New Delhi, India.

Chandan, R. C. (2006). History and consumption trends. In Manufacturing of yogurt and fermented milks. $1^{\text {st }}$ Edn. Blackwell Publishing Professional. Ames, Iowa Pp. 317.

Fahey, J.W. (2005). Moringa oleifera: A review of the medical evidence for its nutritional, therapeutic, and prophylactic properties. Trees Life J., 1:5-15

Indian Standards (1961). IS: 1479 (Part-II). Methods of testing for dairy industry Part-II. Rapid examination of milk. Indian Standards Institution, New Delhi.

Kosikowaski, F. (1982). Cheese and fermented milk products. Kosikowaski F. V. (Ed), Associates Publ., New York Pp, 568

Madukwe, E.U., Ezeugwu, J.O. and Eme, P.E. (2013). Nutrient composition and sensory evaluation of dry Moringa oleifera aqueous extract. Int. J. Basic \& Applied Sci., 13 (3): 1303-1321

Maheta, R. G., Balakrishnan, S. and Aparnathi, K. D. (2014). Standardization of the method for utilization of paneer whey in cultured buttermilk. J. Food Sci. Technol., doi 10.1007/s13197-014-1301-1302

Mistry, V.V. (2001). Fermented milks and cream. In: Marth E. H. and Steele J. L., Eds. Applied Dairy Microbiology, Chapter 9, 2nd edition. Marcel Dekker, New York $\mathrm{Pp}, 301-325$.

Mughal, M. H., Ali, G., Srivasta, P.S. and Iqbal, M. (1999). Improvement of drumstick (M. pterygosperma Gaertn)
- a unique source of food and medicine through tissue culture. Harmdad Med., 42: 37-42

Nadeem, M. M., Abdullah, I., Hussain, S., Inayat, A., Javid, A. and Zahoor, Y. (2013). Antioxidant potential of Moringa oleifera leaf extract for the stabilisation of butter at refrigeration temperature. Czech. J. Food Sci., 31: 332-339

Pandey, A. K. (2013). Chapter 4 Composition and uses. In Drumstick (Moringa oileiferaLamk) A miracle health tree. Agrotech Publishing Academy, Udaipur Pp 60-95.

Ramachandran, C., Peter, K. V. and Gopalakrishnan, P. K. (1980). Drumstick (Moringa oleifera): A multipurpose Indian vegetable. Econ. Bot., 34(3):276-283

Rao, A.V. (2003). Selected technological parameters for manufacture of chhash. M. Sc. Thesis submitted to Anand Agricultural University, Anand.

Salem, A.S., Wafaa, M., Salama, A.M., Hassanein, Hanan, M.A. and Ghandour, E.L. (2013). Enhancement of nutritional and biological values of Labneh by adding dry leaves of Moringa oleifera as innovative dairy products. World Applied Sci. J., 22(11): 1594-1602

Stainier, R.Y., Adelberg, E.A. and Ingrahan, J.L. (1985). In: General Microbiology $4^{\text {th }}$ Ed. MacMillian Pub. Ltd., London Pp 256-258

Steel, R.G.D. and Torrie, J.H. (1980). Principles and Procedures of Statistics. 2nd ed. New York: McGraw-Hill.

Vanajakshi, V., Vijayendra, S.V.N., Varadaraj, M. C., Venkateswaran, G. and Agrawal, R. (2015). Optimization of a probiotic beverage based on Moringa leaves and beetroot. LWT - Food Sci. and Technol., 63(2): 1268-1273 